\title{
Hemilaminectomy Approach Combined with in situ Restoration of Vertebral Laminae for Thoracic Intraspinal Tumors
}

\author{
Torasik Intraspinal Tümörler İcin in situ Vertebral Lamina \\ Restorasyonuyla Kombine Hemilaminektomi Yaklaşımı
}

\author{
Wen-Sheng LI, Chuan CHEN, Hui WANG, Chao-Feng LIANG, Lun LUO, Ying GUO \\ Third Affiliated Hospital of Sun Yat-Sen University, Department of Neurosurgery, Guangzhou, China \\ Corresponding Author: Ying GUO / E-mail: yingguo2@163.com
}

\begin{abstract}
AIM: This study aims to evaluate the hemilaminectomy approach and in situ restoration of vertebral laminae in microsurgery for thoracic intraspinal tumors.

MATERIAL and METHODS: Sixteen patients with thoracic intraspinal tumors, consisting of 6 males and 10 females with a mean age of $47.5 \pm 16.4$ years ranging from 21 to 71 years, underwent surgical treatment with hemilaminectomy approach and in situ restoration of vertebral laminae. All patients were followed up after surgery for 12 to 30 months, involving Frankel grade, spinal instability, and deformity.

RESULTS: Mean operation time was $119.5 \pm 23.0$ minutes. Laminotomy was performed with one vertebral plate in 2 cases, two vertebral plates in 12 cases, and three vertebral plates in 2 cases. Postoperative three-dimensional CT scanning revealed a stable bony reconstruction, and no cerebrospinal fluid leakage or subcutaneous hydrops. Surgical pathology was consistent with preoperative MRI diagnosis. With respect to neurological status, the percentage of good Frankel scale was markedly improved from $37.5 \%$ on admission to $81.3 \%$ at follow-up ( $p<0.05$ ). None of the subjects showed spinal deformity or instability.
\end{abstract}

CONCLUSION: In situ restoration of vertebral laminae maximally preserves the spinal integrity and stability, and reduces postoperative complications including cerebrospinal fluid leakage, pseudomeningocele, spinal deformity, and instability

KEYWORDS: Hemilaminectomy approach, In situ restoration, Vertebral laminae, Thoracic spine, Intraspinal tumors

öz

AMAÇ: Bu çalışma, torasik intraspinal tümörler için mikrocerrahide vertebral laminaların in situ restorasyonu ve hemilaminektomi yaklaşımını değerlendirmeyi amaçlamaktadır.

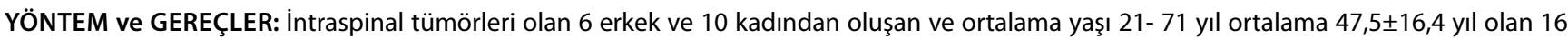
hastaya hemilaminektomi yaklaşımı ve vertebral laminaların in situ restorasyonuyla cerrahi tedavi yapıldı. Tüm hastalar cerrahi sonrasında 12-30 ay boyunca Frankel sınıfı, spinal instabilite ve deformite dahil olmak üzere takip edildi.

BULGULAR: Ortalama ameliyat süresi 119,5 $\pm 23,0$ dakikaydı. Laminotomi 2 vakada bir vertebral plakta 12 vakada iki vertebral plakta ve 2 olguda üç vertebral plakta yapıldı. Postoperatif üç boyutlu BT taraması stabil kemik rekonstrüksiyonu bulunduğunu ve serebrospinal sıvı sızması veya subkütan hidrops olmadığını gösterdi. Cerrahi patolojik preoperatif MRG tanısıyla tutarlıydı. Nörolojik durum açısından iyi Frankel ölçeği yüzdesi hastaneye yatmada \%37,5'ten takipte \%81,3'e arttı ( $\mathrm{p}<0,05)$. Hastaların hiçbirinde spinal deformite veya instabilite görülmedi.

SONUÇ: Vertebral laminaların in situ restorasyonu spinal bütünlük ve stabiliteyi maksimum şekilde korur ve serebrospinal sıvı sızdırma, psödomeningosel, spinal deformite ve instabilite dahil olmak üzere postoperatif komplikasyonları azaltır

ANAHTAR SÖZCÜKLER: Hemilaminektomi yaklaşımı, İn situ restorasyon, Vertebral lamina, Torasik omurga, Intraspinal tümörler

\section{INTRODUCTION}

Meningioma and neurinoma are the most common benign intraspinal tumors, accounting for approximately $53 \%$ of all the intraspinal tumors (26). The thoracic spinal lesions are most common and make up about $80 \%$ of intraspinal tumors $(4,15,27)$. Surgical resection is the only effective treatment for meningioma and neurinoma. The traditional approach to intraspinal lesions is laminectomy, but is associated with a number of postoperative complications including spinal deformity, instability and epidural fibrosis (5, 13, 30). Most cases have adopted the hemilaminectomy approach as it has lower surgical injury and complication rates $(2,3,20)$. At present, the hemilaminectomy approach has been a relatively mature technique for intraspinal tumors. However, in situ restoration of vertebral laminae following hemilaminectomy has seldom been reported. To reduce the injury to normal 
spinal structure and spinal stability, and to maximally recover the normal physiological functions of the spine, we proposed the operative method of hemilaminectomy and in situ restoration of vertebral laminae for intraspinal tumors (Figures $1 A, B, 2$ ). In this study, we treated 16 subjects with thoracic intraspinal tumors, who underwent the less invasive approach, with good preservation of anatomical and physiological spinal functions and less postoperative complications.

\section{MATERIALS and METHODS}

\section{Clinical Information}

Between August 2009 and May 2011, 16 consecutive patients ( 6 males and 10 females with a mean age of $47.5 \pm 16.4$ years ranging from 21 to 71 years) underwent hemilaminectomy and in situ restoration of vertebral laminae for intraspinal tumors. Preoperative symptoms included unilateral motor disturbance in 10 cases, bilateral motor disturbance in 1 case, unilateral extremity sensory disturbance in 6 cases and lower extremity pain in 7 cases. Neurological status on admission evaluated by Frankel grade classification (14) was shown in Table I. There were 1 case of Grade A, 2 cases of Grade B, 7 cases of Grade $C$ and 5 cases of Grade D and 1 case of Grade E on admission. Mean disease duration was $25.3 \pm 16.9$ months, ranging from 2 to 60 months.

\section{Neurological Imaging}

Preoperative MRI revealed intradural extramedullary tumors in all cases. Main tumorous parts were located in the ventral spinal cord in 2 cases, dorsal spinal cord in 3 cases, and on the left side of the spinal cord in 5 cases, right side in 6 cases. There were 10 cases of meningioma with typical dural tail sign in 9 cases, and 6 cases of neurilemmoma. These tumors spanned across one vertebral body in 8 cases, two vertebral bodies in 7 cases, three vertebral bodies in 1 case. Maximal axial diameter ranged from 0.8 to $1.6 \mathrm{~cm}$ (mean $1.27 \pm 0.23 \mathrm{~cm}$ ) (Table I).

\section{Procedure of Surgical Intervention}

1) Microscopic neurosurgical operations were performed in the prone position under general anesthesia. All of the patients in our study were given an adequate preoperative informed consent including possible unknown complication rates. Skin incision was determined according to preoperative MRI and interspinous ligament puncture location. A median vertical incision was performed and the skin and subcutaneous tissues were incised. Along the lateral border of spinous processes, paravertebral muscles were separated for a full exposure of vertebral laminae on the affected side. To avoid damage to facet joints, exfoliation of the muscle and periosteum from spinous processes and vertebral laminae should not exceed the medial border of the articular process (Figure 3A).

2) After exposure of vertebral laminae on the lesion side, the number of incised vertebral laminae was determined according to tumor size for full exposure of the upper and lower pole of the tumor. The range of vertebral laminae

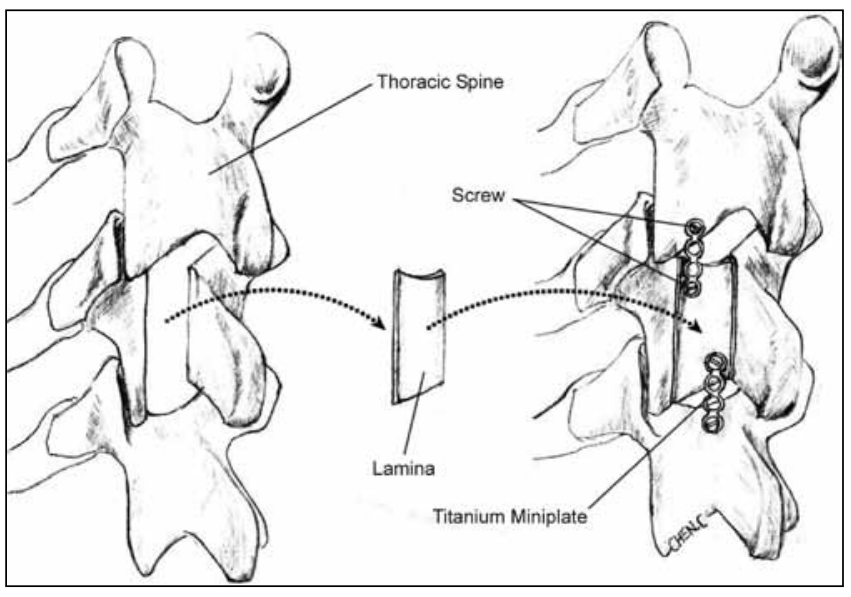

Figure 1: Schematic diagram of in situ restoration of vertebral laminae: A) excised vertebral lamina; B) in situ restoration of vertebral lamina.

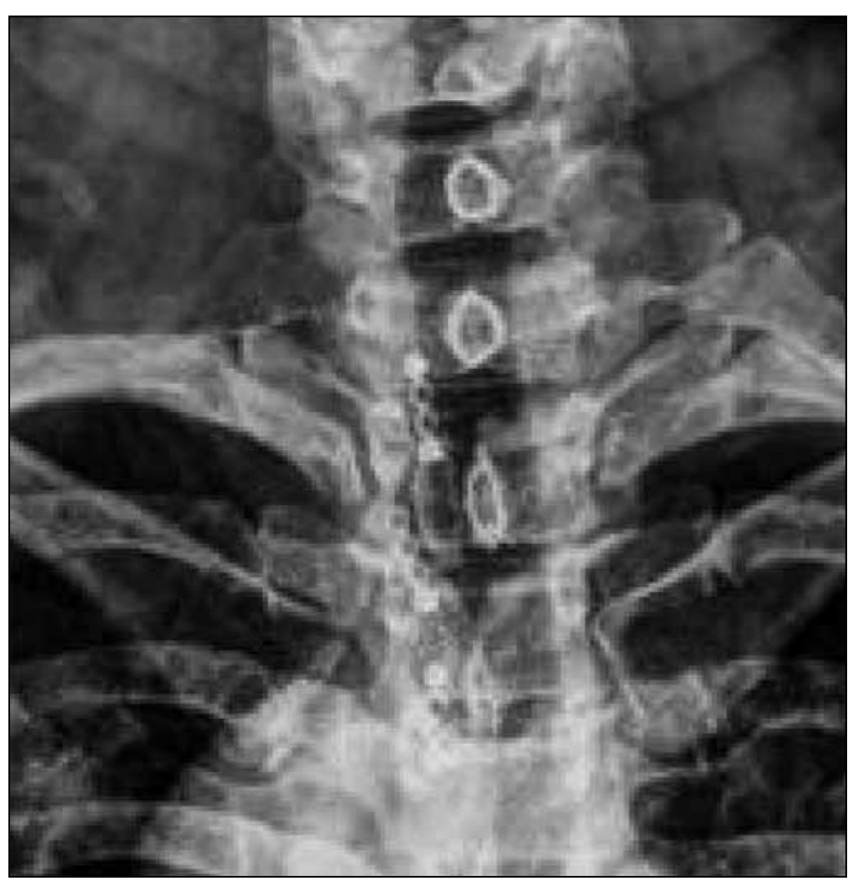

Figure 2: Postoperative thoracic posteroanterior radiography showed good fixation and restoration of the vertebral lamina.

resection did not exceed the costotransverse joint on the lateral side and reached the base of the spinous process on the medial side. If necessary, parts of the spinous process and ligamentum flavum could be removed for wider surgical vision of dural sac (Figure 3B).

3) The tumor was excised in en bloc or piecemeal resection according to the size and blood supply. Small-size tumors were removed with en bloc resection (Figure 3C, 3D). Large tumors on the ventral or ventrolateralspinal side, or grown around the nerve roots, were removed in piecemeal resection. With bipolar electrocoagulation, the attachment point of the tumor was repeatedly cauterized and cauterization range was 
expanded to avoid recurrence. The dura on the attachment site was removed together with the tumor when the tumor was located on the ventral or ventrolateralspinal sides. Defect sites of the dura were repaired with an artificial dura. The dura was sutured in a water-tight fashion to avoid cerebrospinal fluid leakage (Figure 3E).

(4) The excised vertebral laminae were fixed in situ with titanium miniplates and nails with gelfoam cushion on the dura, trying to avoid spinal stenosis (Figure 3F).

\section{Follow Up}

All patients were followed up after surgery for 12 to 30 months (mean 19.7 \pm 5.4 months) by nurses, involving Frankel grade, spinal instability and deformity evaluated by threedimensional reconstruction with a 320-row CT scanner.

\section{Statistical Analysis}

The percentage of good Frankel grade (the ratio of the number of subjects with $\mathrm{D}+\mathrm{E}$ grade to all) was analyzed with Fisher's exact test.

\section{RESULTS}

\section{Surgical Results}

In our study, all the 16 cases with thoracic intraspinal tumors had radical tumor resection and in situ restoration of vertebral laminae. Mean operation time was $119.5 \pm 23.0$ minutes ranging from 72 to 155 minutes. There were no cases of intraoperative blood transfusion or autotransfusion. The average hemoglobin drop after surgery was $1.47 \pm 0.38 \mathrm{~g} / \mathrm{L}$ in the range of 0.9 to $2.1 \mathrm{~g} / \mathrm{L}$. Laminotomy was performed with one vertebral plate in 2 cases, two vertebral plates in 12 cases, and three vertebral plates in 2 cases (Table II).

\section{Postoperative Images and Pathologic Diagnosis}

Postoperative three-dimensional CT scanning with a 320row CT scanner revealed good fixation of vertebral laminae,

Table I: Clinical Features of Patients with Thoracic Intraspinal Tumors

\begin{tabular}{|c|c|c|c|c|c|c|c|c|c|}
\hline $\begin{array}{l}\text { Case } \\
\text { No. }\end{array}$ & $\begin{array}{l}\text { Age } \\
\text { (yrs) }\end{array}$ & Sex & Symptom & $\begin{array}{l}\text { Duration } \\
\text { (m) }\end{array}$ & $\begin{array}{l}\text { Frankel } \\
\text { grade }\end{array}$ & $\begin{array}{l}\text { Diameter } \\
\text { in axis }(\mathbf{c m})\end{array}$ & $\begin{array}{l}\text { Level of } \\
\text { tumor }\end{array}$ & $\begin{array}{l}\text { Location } \\
\text { of tumor }\end{array}$ & $\begin{array}{l}\text { Follow } \\
\text { Up (m) }\end{array}$ \\
\hline 1 & 45 & $M$ & $\begin{array}{l}\text { motor and sensory } \\
\text { disturbance }\end{array}$ & 16 & $\mathrm{~B}$ & 1.3 & T5-6 & left & 25 \\
\hline 2 & 28 & $\mathrm{~F}$ & radiating pain & 23 & $\mathrm{E}$ & 1.0 & $\mathrm{~T} 1$ & right & 18 \\
\hline 3 & 21 & $\mathrm{~F}$ & motor disturbance & 5 & $\mathrm{D}$ & 1.1 & $\mathrm{~T} 11-12$ & dorsal & 28 \\
\hline 4 & 33 & $\mathrm{~F}$ & sensory disturbance & 2 & $\mathrm{D}$ & 1.3 & T7 & right & 19 \\
\hline 5 & 37 & $M$ & $\begin{array}{l}\text { motor disturbance and } \\
\text { radiating pain }\end{array}$ & 6 & C & 1.5 & $\mathrm{~T} 8$ & right & 12 \\
\hline 6 & 58 & $\mathrm{~F}$ & motor disturbance & 17 & $\mathrm{C}$ & 1.4 & T6 & right & 18 \\
\hline 7 & 66 & $M$ & $\begin{array}{l}\text { motor disturbance and } \\
\text { radiating pain }\end{array}$ & 39 & $\mathrm{~B}$ & 0.8 & T3-4 & left & 24 \\
\hline 8 & 54 & $M$ & $\begin{array}{l}\text { motor and sensory } \\
\text { disturbance }\end{array}$ & 27 & $\mathrm{C}$ & 1.5 & T6 & right & 13 \\
\hline 9 & 62 & $\mathrm{~F}$ & sensory disturbance & 42 & $\mathrm{D}$ & 0.9 & $\mathrm{~T} 5$ & dorsal & 21 \\
\hline 10 & 69 & $\mathrm{~F}$ & $\begin{array}{l}\text { motor disturbance } \\
\text { radiating pain }\end{array}$ & 35 & $\mathrm{C}$ & 1.2 & $\mathrm{~T} 7-8$ & ventral & 12 \\
\hline 11 & 71 & $\mathrm{~F}$ & motor disturbance & 60 & $A$ & 1.6 & T9-11 & left & 22 \\
\hline 12 & 25 & M & $\begin{array}{l}\text { motor disturbance and } \\
\text { radiating pain }\end{array}$ & 7 & C & 1.4 & $\mathrm{~T} 11$ & left & 17 \\
\hline 13 & 39 & $\mathrm{~F}$ & sensory disturbance & 19 & $\mathrm{D}$ & 1.2 & T6-7 & right & 14 \\
\hline 14 & 44 & $\mathrm{~F}$ & $\begin{array}{l}\text { motor disturbance and } \\
\text { radiating pain }\end{array}$ & 49 & C & 1.4 & T7 & ventral & 20 \\
\hline 15 & 43 & $M$ & sensory disturbance & 23 & $\mathrm{C}$ & 1.5 & $\mathrm{~T} 4-5$ & left & 22 \\
\hline 16 & 65 & $\mathrm{~F}$ & $\begin{array}{l}\text { motor disturbance and } \\
\text { radiating pain }\end{array}$ & 34 & $\mathrm{D}$ & 1.2 & T7-8 & dorsal & 30 \\
\hline Ave. & 47.5 & & & 25.3 & & 1.27 & & & 19.7 \\
\hline S.D. & 16.4 & & & 16.9 & & 0.23 & & & 5.4 \\
\hline
\end{tabular}

No, number; $\boldsymbol{F}$, female; $\boldsymbol{M}$, male; $\boldsymbol{y r s}$, years; $\boldsymbol{T}$, thoracic; $\boldsymbol{m}$, months; $\mathbf{c m}$, centimeters. 
no spinal stenosis or facet joint injury. There were no cases of cerebrospinal fluid leakage or subcutaneous hydrops. No residual tumor was observed in postoperative MRI (Figure $4 A-D)$. Surgical pathology confirmed 10 cases of meningioma and 6 cases of neurilemmoma, consistent with preoperative MRI diagnosis (Table II).

\section{Changes in Neurological Status}

Neurological statuses on admission and at follow-up were evaluated by Frankel grade classification to evaluate the improvement in neurological function (Table III). Most patients had a better Frankel grade at follow-up. The percentage of good Frankel scale was markedly improved from $37.5 \%$ on admission to $81.3 \%$ at follow-up $(p<0.05)$. Postoperative three-dimensional $\mathrm{CT}$ reconstruction images revealed gradual bone fusion of vertebral laminae without spinal deformity or instability (Figure 5). In addition, the cost of the additional intervention may lead to an increase of hospital charges about $20 \%$.

\section{DISCUSSION}

In 1983, Denis firstly described the three-column model concept of the spine for the explanation of instability of spinal trauma. Biomechanical and pathomechanical studies demonstrated that intact middle and posterior column structures were very critical to spinal stability (21). In traditional laminectomy, the anatomical structures removed usually include the spinous process, vertebral laminae, part of the facet complex, interspinous and supraspinous ligaments, and ligamentum flavum. It may result in gradually-increasing instability or deformity of the spine $(10,16,18)$. In children, the incidence of spinal deformity after laminectomy is up to $88 \%$ with $27 \%$ to $60 \%$ of subjects receiving a second fusion operation (29). To reduce postoperative complications, less invasive procedures such as hemilaminectomy have been developed and disseminated in clinical practice $(12,21,22)$.

\section{Application of Hemilaminectomy Approach}

The intradural extramedullary tumors located dorsal-laterally, ventral-laterally, laterally, and even ventrally, especially in patients with spinal neurinoma and meningioma could be removed via hemilaminectomy $(1,6,8,25)$. But with a limited bone window, a proper size of the tumor is required for hemilaminectomy. According to our surgical experience, tumors less than $2 \mathrm{~cm}$ in diameter and confined within 2 to 3 vertebral bodies could usually be removed via

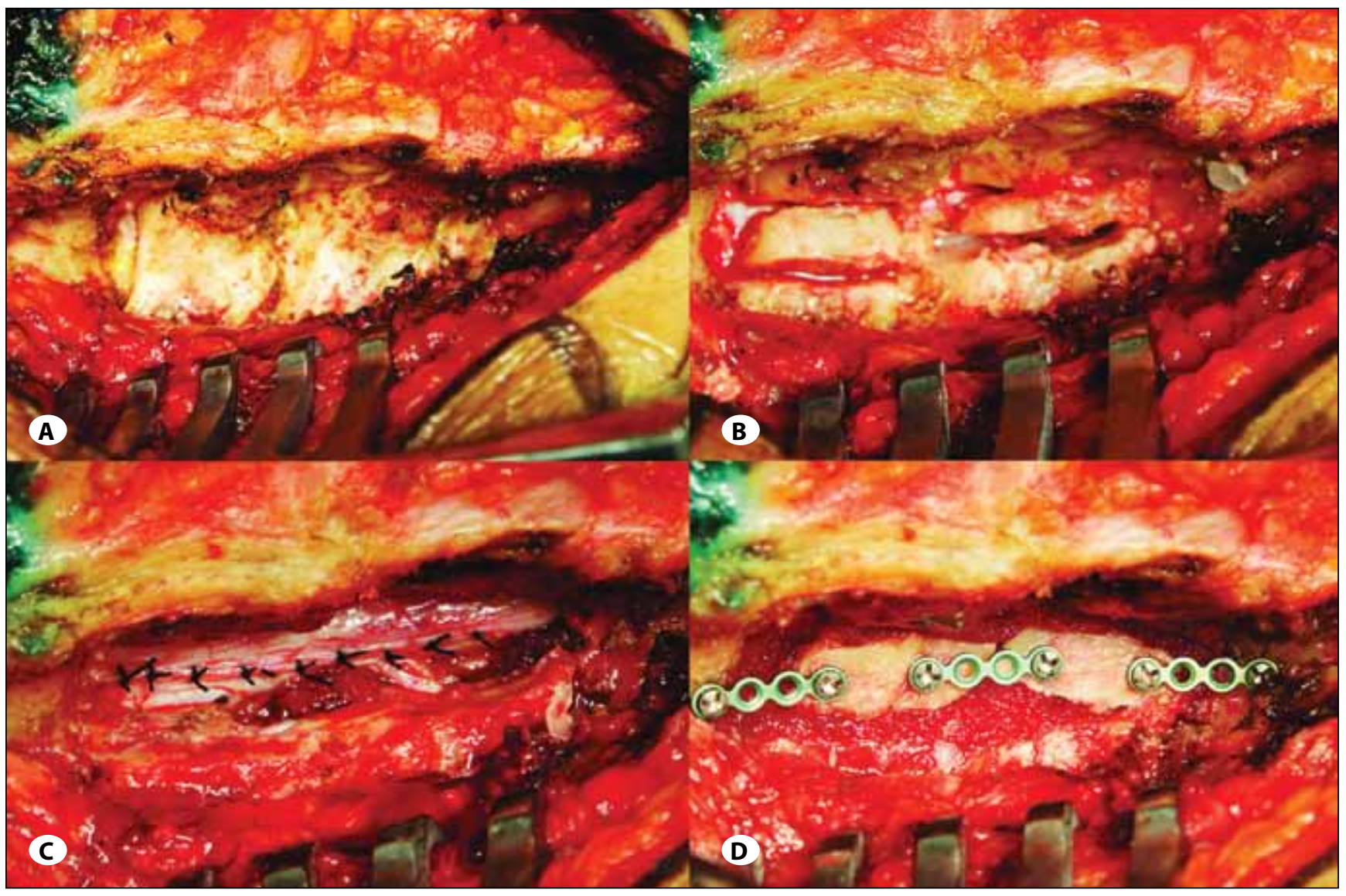

Figure 3: A) Exposed thoracic vertebral laminae during surgery; B) Two segments of vertebral laminae were excised without injury to the articular process, and the interspinous ligament with methylene blue staining were exposed; $\mathbf{C}$ ) The dura was sutured in a watertight fashion after radical tumor resection, without postoperative cerebrospinal fluid leakage; D) The excised vertebral laminae were fixed in situ with titanium miniplates and nails. 
hemilaminectomy. If the tumor occupies less than $1 / 3$ of the spinal canal space, hemilaminectomy could be routinely used with a bone window from the medial border of the articular process on the lateral side to the base of the spinous process on the medial side (28). If the tumor occupies $1 / 3$ to $1 / 2$ of the spinal canal space, parts of the base of the spinous process should be removed for wider surgical vision. If the tumor occupies more than half of the spinal canal space, the base of the spinous process and interspinous ligaments should be removed with a wider range $(7,11)$. For dumbbell tumor involving intervertebral foramen, not appearing in our study, it was reported that hemilaminectomy could also be performed with resection of parts of the articular process (23).

\section{Applicability of Hemilaminectomy Approach for Benign Thoracic Intraspinal Tumors}

Meningioma and neurilemmoma are benign intradural extramedullary spinal tumors, commonly found in the thoracic spinal canal (25). The thoracic spinal canal has its own characteristics. The cervical spinal canal is widest, followed by the lumbar canal. The thoracic spinal canal is narrowest, and the hemilaminar exposure is most limited for the influence of ribs and costotransverse joints. Therefore, it is more difficult to implement treatment with hemilaminectomy approach and in situ restoration of vertebral laminae in the thoracic spinal canal, which has seldom been reported in the world. Bur for the narrow thoracic spinal canal, symptoms and signs of spinal cord compression appear in the early stage

Table II: Hemilaminectomy for Thoracic Intraspinal Tumors

\begin{tabular}{|c|c|c|c|c|c|}
\hline $\begin{array}{l}\text { Case } \\
\text { No. }\end{array}$ & $\begin{array}{l}\text { Operation time } \\
\text { (mins) }\end{array}$ & $\begin{array}{l}\text { Level for } \\
\text { hemilaminectomy }\end{array}$ & $\begin{array}{l}\text { Hemoglobin drop } \\
\qquad(g / L)\end{array}$ & $\begin{array}{l}\text { Frankel grade at } \\
\text { follow-up }\end{array}$ & $\begin{array}{l}\text { Pathological } \\
\text { diagnosis }\end{array}$ \\
\hline 1 & 98 & T5-6 & 1.1 & $\mathrm{D}$ & meningioma \\
\hline 2 & 72 & $\mathrm{~T} 1$ & 1.3 & $\mathrm{E}$ & meningioma \\
\hline 3 & 135 & $\mathrm{~T} 11-12$ & 1.1 & E & neurinoma \\
\hline 4 & 140 & T7-8 & 1.7 & $\mathrm{E}$ & meningioma \\
\hline 5 & 114 & T7-8 & 1.5 & E & meningioma \\
\hline 6 & 126 & T5-6 & 1.6 & C & meningioma \\
\hline 7 & 108 & T3-4 & 0.9 & C & neurinoma \\
\hline 8 & 115 & T5-6 & 1.2 & D & meningioma \\
\hline 9 & 87 & T5 & 1.0 & E & meningioma \\
\hline 10 & 140 & T7-9 & 2.1 & D & meningioma \\
\hline 11 & 155 & T9-11 & 1.9 & B & neurinoma \\
\hline 12 & 103 & $\mathrm{~T} 11-12$ & 1.9 & $\mathrm{E}$ & neurinoma \\
\hline 13 & 109 & T5-6 & 1.2 & E & neurinoma \\
\hline 14 & 137 & T7-8 & 1.8 & D & meningioma \\
\hline 15 & 124 & T4-5 & 1.3 & D & neurinoma \\
\hline 16 & 149 & T7-8 & 1.9 & D & meningioma \\
\hline Ave. & 119.5 & & 1.47 & & \\
\hline S.D. & 23.0 & & 0.38 & & \\
\hline
\end{tabular}

No, number; mins, minutes; $\mathbf{T}$, thoracic; $\mathbf{g} / \mathbf{L}$, gram per liter; $\mathbf{c m}$, centimeters.

Table III: Neurological Statuses on Admission and at Follow-Up Evaluated by Frankel Grade Classification

\begin{tabular}{|l|c|c|}
\hline \multirow{2}{*}{ Frankel grade } & \multicolumn{2}{|c|}{ Number of cases } \\
\hline A: No motor or sensory function below the level of injury & Admission & Follow-up \\
\hline B: Some preserved sensory functions & 1 & 1 \\
\hline C: Some preserved motor functions, unable to walk & 2 & 2 \\
\hline D: Preserved useful motor functions, able to walk & 5 & 6 \\
\hline E: Normal motor and sensory functions & 1 & 7 \\
\hline Total & 16 & 16 \\
\hline
\end{tabular}


of disease when the tumor is still very small. Thus the tumor can be totally removed by hemilaminectomy approach with spinal stability maximally preserved. Meanwhile, thoracic lesions seldom form dumbbell structures like cervical or lumbar spinal tumors, for shelter effects of costotransverse joint, narrow thoracic laminae interval space, and imbricate arrangement of parts of vertebral laminae. So we consider that more patients with thoracic spinal tumors are suitable for hemilaminectomy approach, compared to those with cervical or lumbar spinal tumors. In our study, all of the 10 thoracic meningiomas and 6 thoracic neurilemmomas are intradural extramedullary spinal tumors with transverse diameter below or equal to $1.6 \mathrm{~cm}$. All cases had total tumor resection with hemilaminectomy approach.

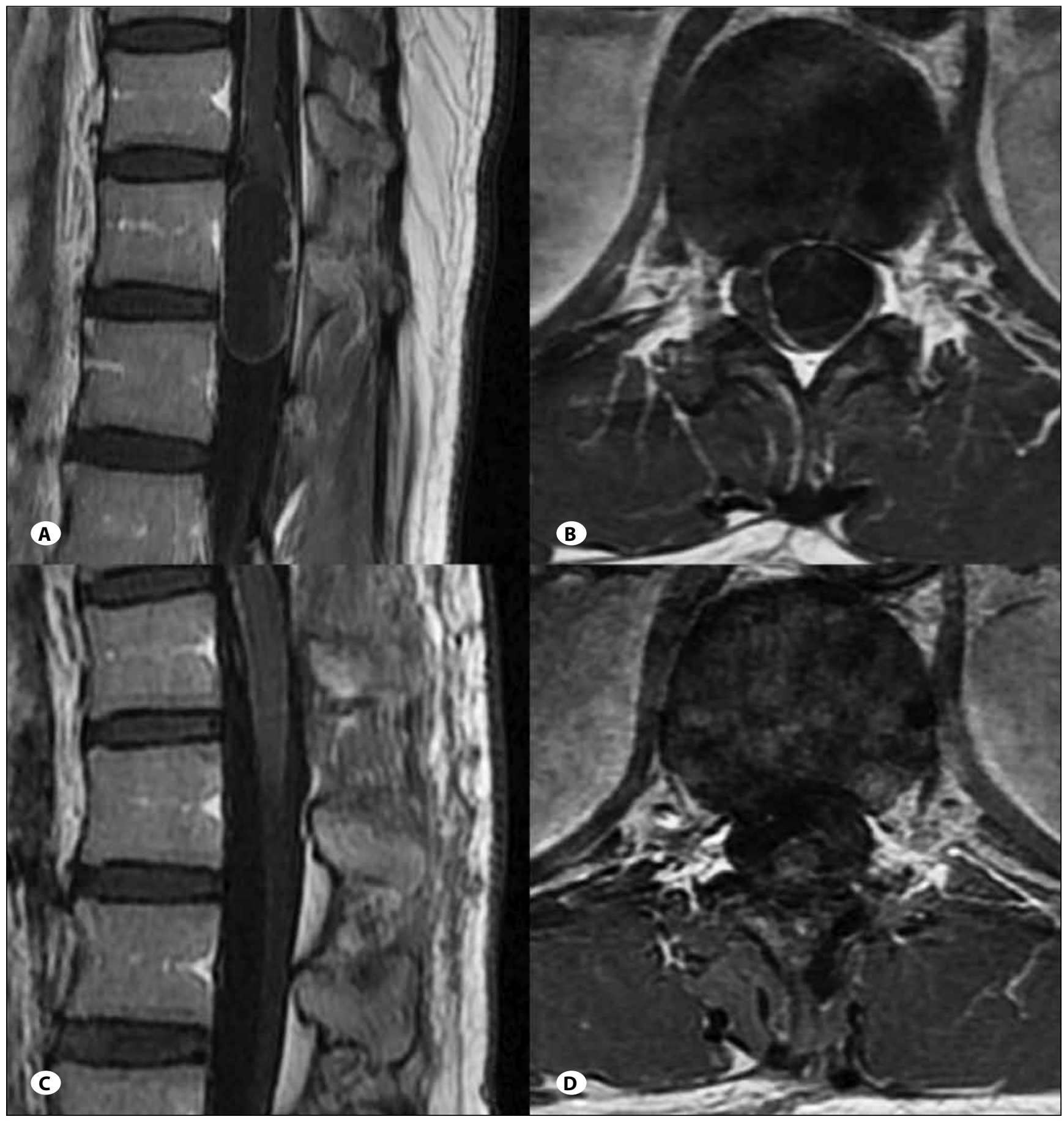

Figure 4: Preoperative MRI showed sagittal (A) and axial (B) views of the tumor, and postoperative MRI showed the neurilemmoma was removed with en bloc resection (C, D). 


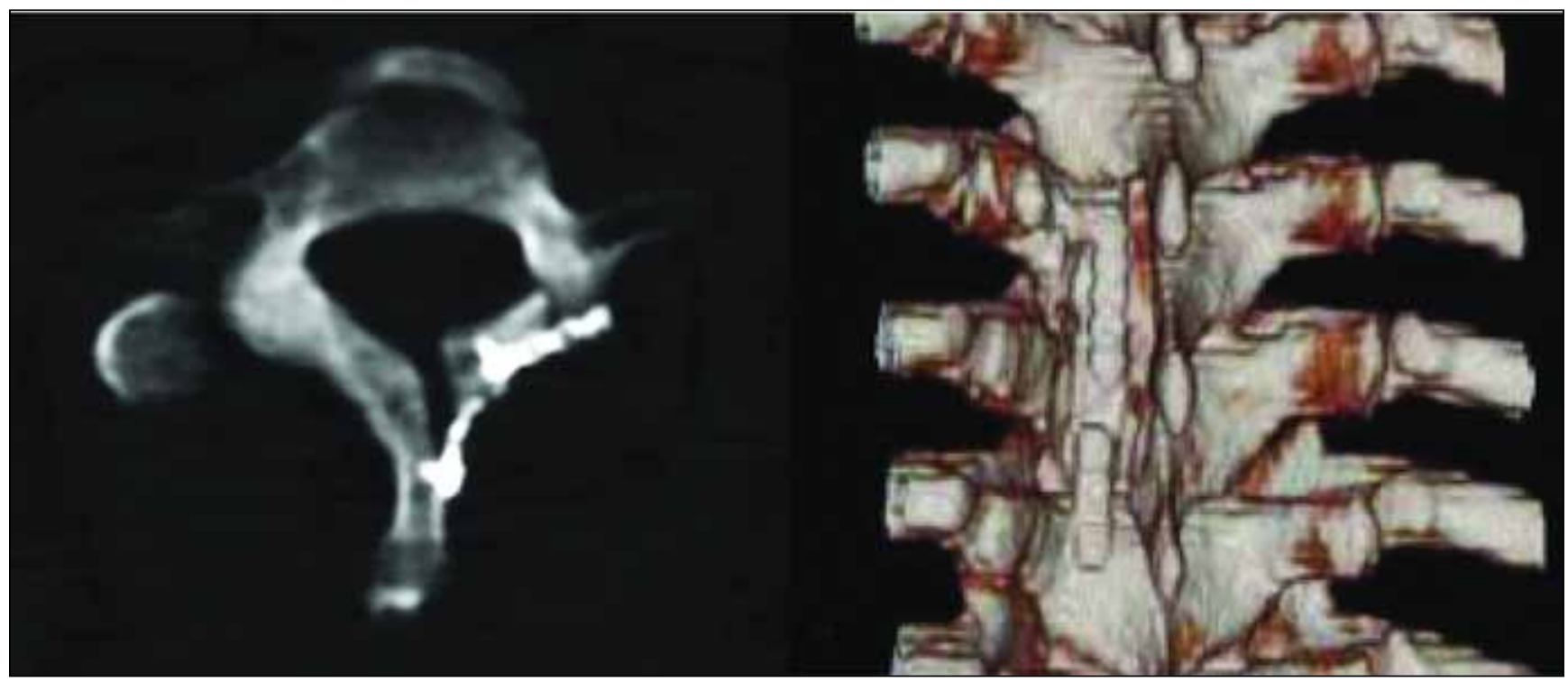

Figure 5: Postoperative three-dimensional CT reconstruction with a 320-row CT scanner revealed good fixation and gradual bone fusion of vertebral laminae without spinal deformity.

\section{Location Technique of Thoracic Intraspinal Tumors}

As mentioned above, thoracic intraspinal tumors are usually very small at diagnosis. To avoid damage to posterior column structures, preoperative precise location seems very important in hemilaminectomy with limited hemilaminar exposure. For dense arrangement of the thoracic spinous process and lack of an effective surface location marker, preoperative location is more difficult in the thoracic spine than in the cervical and lumbar spine. At present, surface location and intraoperative localization are often used in thoracic spinal surgery. In surface location, capsules or metals are pasted on the dorsal surface according to preoperative MRI or CT. A C-arm X-ray apparatus is used for intraoperative localization during surgery. But according to our own experience, both of the two location methods lack real-time, effective instruction and guidance during surgery. No matter which location method is used, there are deviations resulting from position difference and displacement of the skin and soft tissue during surgery. Given this background, we adopted a self-initiated method of interspinous ligament puncture location before surgery. The concrete operation method is shown in Figure 6. One patient had a thoracic lesion at the T5-T6 level. According to the position of the $\mathrm{C} 7$ spinous process, spinous process of T5-T6 was found and a metal marker was pasted on the skin. A lateral radiograph of the thoracic spine with atlas and axis was taken to confirm the position of the metal marker and the T5-T6 interspace of spinous processes. A 2-mL syringe was inserted through the T5-T6 interspace into T5-T6 interspinous ligament. Another lateral radiograph was taken to confirm the T5-T6 interspace (Figure 6). Then $0.2 \sim 0.4 \mathrm{ml}$ of methylene blue and lidocaine at a 1:1 ratio were injected and the syringe was taken out. A cross mark was made on the skin puncture point and the puncture location was completed. The interspinous ligament with methylene blue staining could be seen during separation of soft tissues and paravertebral muscles. The spinous processes near the stained interspinous ligament were the target spinous processes. Finally, T5 and T6 vertebral laminae were found along the base of spinous processes. Compared with traditional location methods, the method of interspinous ligament puncture location is complicated and invasive. But this method has provided effective and accurate guidance to the surgeon, shortening the operating time and avoiding the damage to posterior column structures resulting from location deviations. It is worth to be applied extensively in clinical practice. There are a few points need to be emphasized: (1) Lidocaine is used to reduce the irritation caused by methylene blue and relieve pain; (2) Small dose injection $(0.2 \sim 0.4 \mathrm{ml})$ and injection into the dense interspinous ligament are adopted to avoid diffusion of excessive methylene blue in the soft tissue in case of loss of positioning and guidance functions; (3) For overweight patients, the syringe can be replaced by a spinal puncture needle for puncture and rejection with strict control of insertion depth; (4) As an invasive procedure, the patient or family members are given an adequate preoperative informed consent; (5) If the lateral radiograph after interspinous ligament puncture finds deviations from target interspace, the syringe need not to be taken out. As for our own experience, even if the injection site deviates from the target spinous process for two segments, the stained interspinous ligament can be seen through the skin incision of normal length (Figure 3B). With intraoperative adjustment, the target vertebral lamina can be easily found out. We have used this location method till now and the guidance accuracy for the target vertebral lamina is up to $100 \%$. 


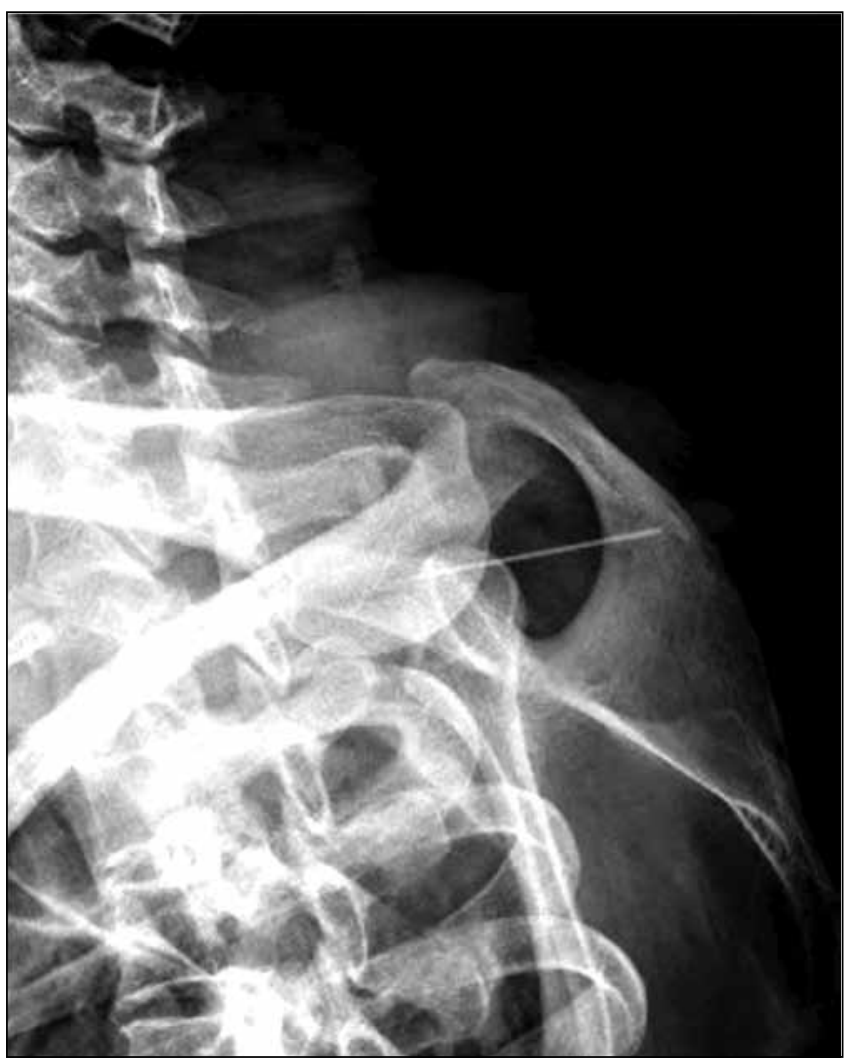

Figure 6: Preoperative lateral radiograph of the thoracic spine showed a syringe needle was inserted into the interspinous ligament.

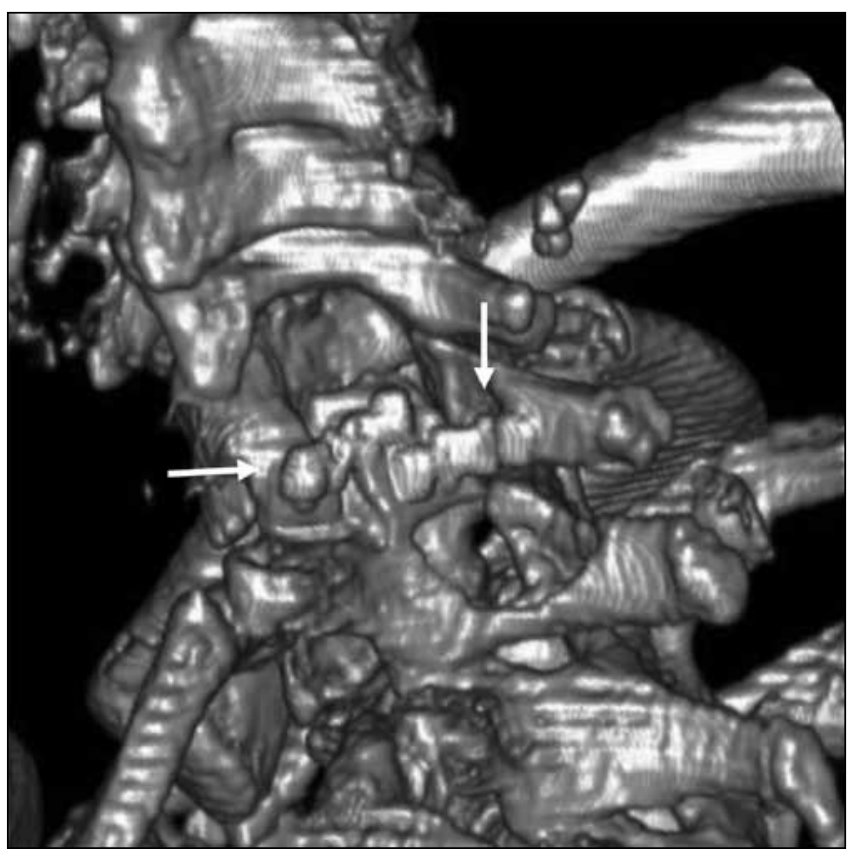

Figure 7: Transverse fixation with titanium miniplates was chosen, if more bone substance was removed from the upper and lower edge of the bone window during operation.

\section{Necessity of in Situ Restoration of Vertebral Laminae}

It has been widely recognized that hemilaminectomy approach dose little damage to posterior column structures and articular processes and has no significant effect on spinal integrity and stability. Meanwhile, with small fenestration and muscle protection, vertebral lamina fenestration does not significantly increase the probability of spinal injury. We consider it is still necessary to have in situ restoration of vertebral laminae after hemilaminectomy. Reasons are as follows: 1) Degreif et al. (9) reported that laminotomy, hemilaminectomy and laminectomy caused rotational stability loss of $6 \%, 20 \%$ and $27 \%$, respectively. So, the spinal stability is closely related to the range of vertebral lamina removal; 2) In situ restoration of vertebral laminae after hemilaminectomy maximally preserves the spinal integrity; 3 ) In situ restoration minimizes the bone defect and injury, facilitating the bone healing of vertebral laminae (17); 4) It maximally preserves the integrity of vertebral laminae, reducing the incidence of cerebrospinal fluid leakage and subcutaneous hydrops; 5) The procedure can be easily completed without prolonged operation time or increased operation difficulty. In view of the above, all the 16 patients in our study successfully underwent in situ restoration of vertebral laminae after hemilaminectomy, without postoperative cerebrospinal fluid leakage or subcutaneous hydrops.

\section{Fixation Method of in Situ Restoration of Vertebral Laminae}

In our study, the excised vertebral laminae were fixed in situ with titanium miniplates and nails instead of silk threads, in consideration of the high firmness and operation convenience of titanium miniplates. Although titanium miniplates may influence imaging observation, $\mathrm{CT}$ images are seldom affected and MRI sequence optimization can minimize the influence $(19,24)$. The titanium nail was tried to be placed in the thick bone in case the tip penetrates through the vertebral lamina and damage the endorachis. It will be more convenient and reasonable to have transverse fixation with titanium miniplates, if more bone substance is removed from the upper and lower edge of the bone window (Figure 7). The excised vertebral lamina can rotate around its long axis or rotate 90 degrees horizontally for maximum restoration of the integrity of the vertebral arch. For children or teenagers, it will be more necessary to have in situ restoration of vertebral laminae than adults (29). But considering the growth and development of children, titanium miniplates are no longer suitable for fixation. Then, absorbable materials or sutures can be used for in situ restoration of vertebral laminae, preserving the spinal stability without influence on growth and development or postoperative imaging observation (12).

\section{CONCLUSIONS}

The thoracic intraspinal tumors have clinical features of early onset, small size and rare dumbbell types, which makes it suitable for hemilaminectomy. Hemilaminectomy approach is of rapid recovery and good postoperative preservation of 
the spinal stability. In situ restoration of vertebral laminae was successfully performed in this study. Although it increases hospital charges to some extent, the method is simple to operate and maximally preserves the spinal integrity and stability, facilitating the bone fusion and reducing postoperative complications. It is worth to be applied extensively in clinical practice.

\section{REFERENCES}

1. Abbott R, Feldstein N, Wisoff JH, Epstein FJ: Osteoplastic laminotomy in children. Pediatr Neurosurg 18:153-156, 1992

2. Asazuma T, Nakamura M, Matsumoto $M$, Chibo K, Toyama Y: Postoperative changes of spinal curvature and range of motion in adult patients with cervical spinal cord tumors: Analysis of 51 cases and review of the literature. J Spinal Disord Tech 17:178-182, 2004

3. Balak N: Unilateral partial hemilaminectomy in the removal of a large spinal ependymoma. Spine J 8:1030-1036, 2008

4. Brant WE, Helms CA: Fundamentals of diagnostic radiology. New York: Lippincott Williams and Wilkins, 2006

5. Cemil B, Tun K, Kaptanoglu E, Kaymaz F, Cevirgen B, Comert A, Tekdemir I: Use of pimecrolimus to prevent epidural fibrosis in a postlaminectomy rat model. J Neurosurg Spine 11: 758-763, 2009

6. Cherqui A, Kim DH, Kim SH, Park HK, Kline DG: Surgical approaches to paraspinal nerve sheath tumors. Neurosurg Focus 22:E9, 2007

7. Chiou SM, Eggert HR, Laborde G, Seeger W: Microsurgical unilateral approaches for spinal tumour surgery: Eight years' experience in 256 primary operated patients. Acta Neurochir (Wien) 100:127-133, 1989

8. Conti P, Pansini G, Mouchaty H, Capuano C, Conti R: Spinal neurinomas: Retrospective analysis and long-term outcome of 179 consecutively operated cases and review of the literature. Surg Neurol 61:34-43; discussion 44, 2004

9. Degreif J, Wenda K, Runkel M, Ritter G: Rotational stability of the thoracolumbar spine after interlaminar ultrasound window, hemilaminectomy and laminectomy. A comparative experimental study. Unfallchirurg 97:250-255, 1994

10. Deutsch H, Haid RW, Rodts GE, Mummaneni PV: Postlaminectomy cervical deformity. Neurosurg Focus 15:E5, 2003

11. Eggert HR, Scheremet R, Seeger W, Gaitzsch J: Unilateral microsurgical approaches to extramedullary spinal tumours. Operative technique and results. Acta Neurochir (Wien) 67:245-253, 1983

12. Fessler RG, O'Toole JE, Eichholz KM, Perez-Cruet MJ: The development of minimally invasive spine surgery. Neurosurg Clin N Am 17:401-409, 2006

13. Fourney DR, Gokaslan ZL: Spinal instability and deformity due to neoplastic conditions. Neurosurg Focus 14:e8, 2003

14. Frankel HL, Hancock DO, Hyslop G, Melzak J, Michaelis LS, Ungar GH, Vernon JD, Walsh JJ: The value of postural reduction in the initial management of closed injuries of the spine with paraplegia and tetraplegia. Paraplegia 7:179-192, 1969
15. Kansal R, Mahore A, Dange N: Giant intramedullary epidermoid extending from the brain stem to the upper thoracic spinal cord. Turkish Neurosurgery 22:452-453, 2012

16. Kaptain GJ, Simmons NE, Replogle RE, Pobereskin L: Incidence and outcome of kyphotic deformity following laminectomy for cervical spondylotic myelopathy. J Neurosurg 93:199-204, 2000

17. Kato $Y$, Kaneko K, Kataoka H, Kojima T, Imajyo $Y$, Taguchi T: Cervical hemilaminoplasty: Technical note. J Spinal Disord Tech 20:296-301, 2007

18. Koch-Wiewrodt D, Wagner W, Perneczky A: Unilateral multilevel interlaminar fenestration instead of laminectomy or hemilaminectomy: An alternative surgical approach to intraspinal space-occupying lesions. Technical note. J Neurosurg Spine 6:485-492, 2007

19. O'Brien MF, Peterson D, Casey AT, Crockard HA: A novel technique for laminoplasty augmentation of spinal canal area using titanium miniplate stabilization. A computerized morphometric analysis. Spine (Phila Pa 1976) 21:474-483; discussion 484, 1996

20. O'Toole JE, Eichholz KM, Fessler RG: Minimally invasive approaches to vertebral column and spinal cord tumors. Neurosurg Clin N Am 17:491-506, 2006

21. Ogden AT, Bresnahan L, Smith JS, Natarajan R, Fessler RG: Biomechanical comparison of traditional and minimally invasive intradural tumor exposures using finite element analysis. Clin Biomech (Bristol, Avon) 24:143-147, 2009

22. Oktem IS, Akdemir H, Kurtsoy A, Koc RK, Menku A, Tucer B: Hemilaminectomy for the removal of the spinal lesions. Spinal Cord 38:92-96, 2000

23. Ozawa H, Kokubun S, Aizawa T, Hoshikawa T, Kawahara C Spinal dumbbell tumors: An analysis of a series of 118 cases. J Neurosurg Spine 7:587-593, 2007

24. Purvines SH, Pritz MB: Cervical hemilaminectomy reconstruction: Technical note. Spine (Phila Pa 1976) 25:1278-1282, 2000

25. Safavi-Abbasi S, Senoglu M, Theodore N, Workman RK, Gharabaghi A, Feiz-Erfan I, Spetzler RF, Sonntag VK: Microsurgical management of spinal schwannomas: Evaluation of 128 cases. J Neurosurg Spine 9:40-47, 2008

26. Schellinger KA, Propp JM, Villano JL, McCarthy BJ: Descriptive epidemiology of primary spinal cord tumors. J Neurooncol 87:173-179, 2008

27. Tan S, Kurt A, Okutan O, Keskin S: Ct findings of a thoracic vertebral hemangioma presenting with acute neurological symptoms. Turkish Neurosurgery 21:113-115, 2011

28. Tredway TL, Santiago P, Hrubes MR, Song JK, Christie SD, Fessler RG: Minimally invasive resection of intraduralextramedullary spinal neoplasms. Neurosurgery 58:ONS5258; discussion ONS52-58, 2006

29. Yao KC, McGirt MJ, Chaichana KL, Constantini S, Jallo Gl: Risk factors for progressive spinal deformity following resection of intramedullary spinal cord tumors in children: An analysis of 161 consecutive cases. J Neurosurg 107:463-468, 2007

30. Yasuoka S, Peterson HA, Laws ER, Jr, MacCarty CS: Pathogenesis and prophylaxis of postlaminectomy deformity of the spine after multiple level laminectomy: Difference between children and adults. Neurosurgery 9:145-152, 1981 